IJLR: International Journal of Law Recontruction

Volume 4, Number 2, September 2020

DOI : http://dx.doi.org/10.26532/ijlr.v4i2.9875

\title{
REVITALIZATION OF INDONESIAN ULEMA COUNCIL FATWA ABOUT INTELLECTUAL PROPERTY PROTECTION
}

\author{
Nugraha Pranadita \\ Nusantara Islamic University \\ nugpra@yahoo.com
}

\begin{abstract}
One of the issues that is both national and international is the issue of intellectual property rights. This is because intellectual property rights have economic value and can be transferred. The purpose of this study is to provide an overview of the importance of revitalizing the fatwa of the Indonesian Ulema Council on the protection of Intellectual Property Rights because it is substantially in accordance with sharia. The research method used is normative juridical by using a conceptual approach and a statutory approach together. The findings of this study are that the fatwa of the Indonesian Ulema Council regarding the protection of Intellectual Property Rights is no longer relevant, so it is necessary to make improvements by issuing a new fatwa as a substitute, or by revising an existing fatwa with various improvements. Meanwhile, the implication of this research is that there is a need to issue a new fatwa by the Indonesian Ulema Council related to the protection of Intellectual Property Rights that is in accordance with current needs and can anticipate future needs.
\end{abstract}

Keywords: Fatwa, IPR, MUI, and Protection.

\section{A. INTRODUCTION}

In life in society, humans can be categorized as individual creatures and social beings together. Humans are intelligent beings ${ }^{1}$ (who have a healthy mind $^{2}$ ), who are able to make choices from various existing variables, using a certain consideration that is considered correct.

As individual beings, humans are individuals who live independently and are free because they have no organic relationship with other individuals ${ }^{3}$. An individual being is an integrated whole, cannot be divided and has a distinctive characteristic as its identity that distinguishes it from other individuals ${ }^{4}$. We are familiar with the personality of these individuals ${ }^{5}$. Individual personality is composed of elements that are objective (eg, physical characteristics), and elements that are subjective (eg; feelings).

1 KBBI Daring, Human, https://kbbi.kemdikbud.go.id/entri/manusia, downloaded on Friday May 15,2020

2 KBBI Daring, Common sense, https://kbbi.kemdikbud.go.id/entri/akal\%20budi, downloaded on Friday May 15, 2020

3 KBBI Daring, Individual, https://kbbi.kemdikbud.go.id/entri/individu, downloaded on Friday May 15, 2020

4 Herimanto \& Winarno, Basic Social and Cultural Sciences, Bumi Aksara, Jakarta, 2008, Page. 41

5 Darmansyah, Basic Social Sciences, Usaha Nasional, Surabaya, 1986, Page. 69 
Elements that are objective are relatively easy to compare with a particular reference, while elements that are subjective are relatively difficult to find references. As an example; feelings of guilt experienced by someone can be ended by committing suicide, or by doing something that can make up for or reduce the feeling of guilt ${ }^{6}$.

Humans can also be seen as social beings because they have the desire to live with other humans in a certain group. The association of humans with one another in society allows these humans to develop as fully human beings as possible ${ }^{7}$. The combination of several human individuals so that it can be categorized as a group or community is marked by the communication between these human individuals. Communication that occurs between human individuals in question is caused due to the needs of each individual who forced him to meet those needs. In this case there are needs of economic value where to obtain it requires sacrifice, and there is also a need to fulfill it does not require sacrifice because it is free goods. "O people! Indeed, We have created you from a man and a woman, then We made you nationals and tribes so that you know each other. Surely the most noble of you in the sight of Allah is the most pious. Truly, Allah is AllKnowing, All-rounder, "QS 49:138.

The group of human individuals starts from the smallest, namely; family, increased to a larger group such as; clan, tribe, nation (state), and international community (community of nations) ${ }^{9}$. The family is the basic structure of forming society. Thus the anomaly contained in the community can be analyzed by understanding the family relationships that take place in the community ${ }^{10}$. Society is a representation or output from the combined projections of human individuals in it which are then processed in the family ${ }^{11}$. The life experiences of individuals in their groups form certain standards or norms that require the individual to comply with them ${ }^{12}$.

As an integrated whole, according to Aristotle, humans are the sum of certain independent abilities, such as the vegetative abilities of eating and breeding. Humans as social beings have the ability; (1) sensitive, such as; move to observe passion and feeling, and (2) intellectual abilities, such as; willful and smart ${ }^{13}$. In other words Aristotle argues that humans as a whole as a whole is when humans can collaborate the nature of the individual with its social nature.

Individuals become part of the community because there are needs that cannot be met by themselves. Individuals are motivated by unmet needs. When these needs are met, then it will encourage other higher

6 H.M. Arifin Noor, Basic social knowledge, Pustaka Setia, Bandung, 1999, Page. 73

7 W.A. Gerungan, Social Psychology, Eresco, Bandung, 1996, Page. 25

8 Qur'an Kemenag, Q.S 49:13, https://quran.kemenag.go.id/share/?q=4625\#, downloaded Saturday, May 16, 2020

9 Herimanto \& Winarno, Basic Social and Cultural Sciences, Bumi Aksara, Jakarta, Page. 45

10 William J. Goode, Family Sociology, Bumi Aksara, Jakarta, 2007, Page. 2

11 Darmansyah, Basic Social Sciences, Usaha Nasional, Surabaya, 1986, Page. 80

12 Syamsu Yusuf \& Juntika Nur Ihsan, Personality Theory, Rosda Karya, Bandung, 2008, Page. 44

13 W.A. Gerungan, Social Psychology, Eresco, Bandung, 1996, Page. 22 
needs, which demand to be met as well. Basically, according to Maslow's human needs can be divided into low-level needs and high-level needs as shown below ${ }^{14}$.

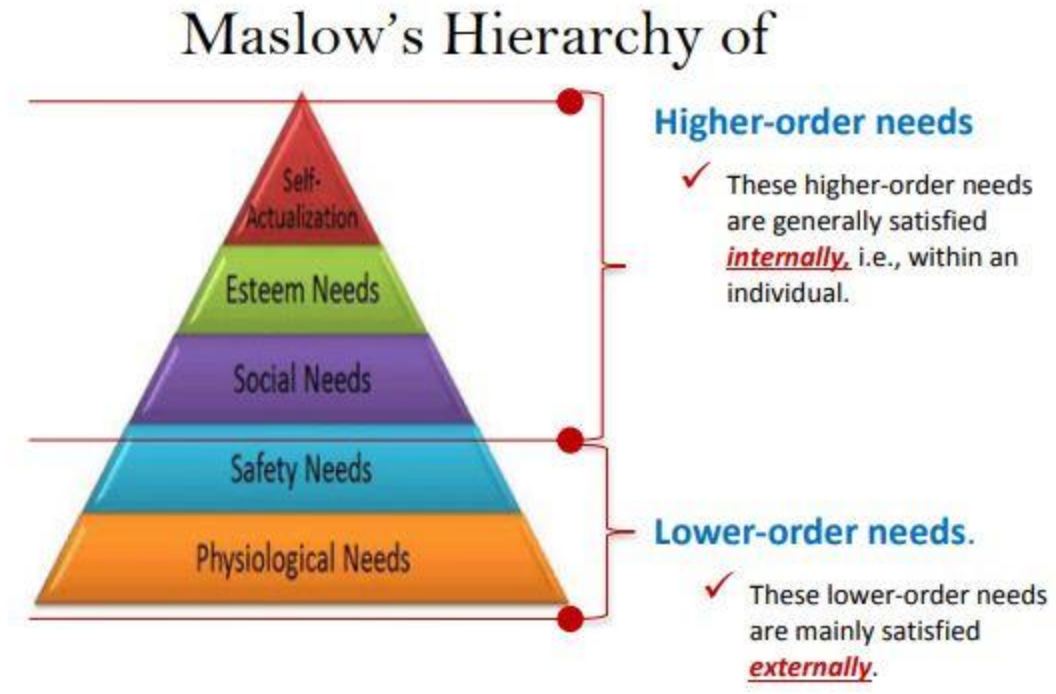

Figure 1. Theory of Malow's Needs ${ }^{15}$

Along with changing times, Maslom's theory of needs also needs to be criticized further. As an example; Initially, the need related to the availability of internet network was not a basic need, but the reality now; for certain circles, the availability of internet networks is a basic requirement. Especially when the Covid-19 pandemic is happening where various activities are carried out at home, the need for internet network availability becomes even more important.

Because most human needs cannot be fulfilled by themselves, then to use them products (goods and services) produced by the intended product providers. That is what causes a product to have economic value, so to obtain it requires sacrifice. To make a product certainly requires business (sacrifice), so the product must be protected in an effort to protect the business of the product maker in question. One legal mechanism that can provide protection to the business carried out by someone who produces the product is through the protection of Intellectual Property Rights.

In Indonesia the protection of Intellectual Property Rights is part of the positive law. On the other hand, the majority of Indonesian people who are Muslim, as in other countries where the majority of the population is Muslim, long for legal protection in accordance with Islamic law ${ }^{16}$. This is

14 Meilanny Budiarti S., Unravel the Basic Concepts of Humans as Individuals Through Social Relations They Build, Prosiding KS: Riset \& PKM, Vol.: 4, No.: 1, ISSN: 2442-4480, Page. 105.

15 Meilanny Budiarti S., Unravel the Basic Concepts of Humans as Individuals Through Social Relations They Build, Prosiding KS: Riset \& PKM, Vol.: 4, No.: 1, ISSN: 2442-4480, Page. 105.

16 Edy Santoso, Islamic Law Concept On International Trade Law Related To Copyright Issues In Indonesia And Turkey, Research Report, Turkish Religious Foundation, Centre for Islamic Studies, Istanbul, 2014 
caused by the fact that Islam is not only about how people worship God, but also about how humans should interact with fellow human beings in society. "Hablum minallah wa hablum minannas (relating religious deeds to God and doing good to fellow human beings)"17. Based on this thought, it is appropriate and proper to protect Intellectual Property Rights based on Islamic law in Indonesia.

This study specifically criticizes the existence of an MUI fatwa on IPR protection that is expected to help the development of the national economy through increasing the competitiveness of the Indonesian people in the field of technology, where in fact the MUI fatwa is less optimized so that it only serves as historical evidence that there has been an MUI fatwa that provides legal protection of Intellectual Property Rights. Based on that, this research is important to be carried out so that the MUI fatwa can function again as it should, namely; provide legal protection for IPR.

The purpose of this research is to analyze the suitability of the MUI fatwa concerning Intellectual Property Rights Protection with positive legal developments related to the Protection of Intellectual Property Rights in Indonesia today, where it is known that there have been several changes to the law related to the protection of Intellectual Property Rights after the issuance of the MUI fatwa. . This is important to do because the majority of Indonesian people are Muslim, who of course have a desire to implement Islamic law in their daily lives. Based on this thought, the revitalization of the MUI fatwa related to the protection of Intellectual Property Rights is something that must be implemented.

\section{B. RESEACH METHODS}

This research is normative legal research ${ }^{18}$ or doctrinal legal research $^{19}$ using the statutory approach and conceptual approach ${ }^{20}$ simultaneously. The legislative approach is needed because this research is related to the existence of written law in the form of the fatwa of the Indonesian Ulema Council, where the existence of the fatwa is significantly influenced by the laws and regulations used as the basis for its formation. While the concept approach is used by researchers to be able to describe how the substance of the MUI fatwa should be integrated with positive law in Indonesia, particularly integrated with legislation related to IPR protection in Indonesia. The research data used are data in the form of legislation and expert opinions contained in reference books or other sources related to a

17 M. Sholeh Kurniawan \& Abdullah Alawi, Four Humans That Live Will Not Be Losses, https://www.nu.or.id/post/read/73580/empat-manusia-yang-hidup-tak-akan-rugi-, downloaded Saturday, May 16, 2020

18 Salim HS. Dan Erlies Septiana Nurbani, Application of Legal Theory in Thesis and Dissertation Research, Raja Grafindo Persada, Jakarta, 2013, Page. 11. See also Bambang Sunggono, Legal Research Methodology, RajaGrafindo Persada, Jakarta, 2013, Page. 41.

19 Ibid.

20 Johnny Ibrahim, Normative Law Theory \& Research Methodology, Bayumedia Publishing, Malang, 2012, Page. 306-307. See also Salim HS. Dan Erlies Septiana Nurbani, Application of Legal Theory in Thesis and Dissertation Research, RajaGrafindo Persada, Jakarta, 2013, Page. 17. See also Peter Mahmud Marzuki, Revised Edition of Legal Research, Kencana, Jakarta, 2013, Page. 177-180. 
particular subject. The secondary data is the primary legal material of this study.

\section{DISCUSSION}

When the Indonesian Ulema Council Fatwa Number: 1 / MUNAS VII / MUI / 5/2005 concerning Protection of Intellectual Property Rights (IPR) was set on July 28, 2005, IPR Protection in the Indonesian legal system was carried out according to the provisions contained in the legislation. the rules as follows:

1. Law of the Republic of Indonesia Number 29 Year 2000 Regarding Protection of Plant Varieties.

2. Law of the Republic of Indonesia Number 30 of 2000 concerning Trade Secrets.

3. Law of the Republic of Indonesia Number 31 of 2000 concerning Industrial Design.

4. Law of the Republic of Indonesia Number 32 of 2000 concerning Layout Design of Integrated Circuits.

5. Law of the Republic of Indonesia Number 14 of 2001 concerning Patents.

6. Republic of Indonesia Law Number 15 Year 2001 Concerning Trademarks.

7. Law of the Republic of Indonesia Number 19 of 2002 concerning Copyright.

The existence of the aforementioned law becomes an inseparable part of the existence of the fatwa itself because the definitions contained in the law are explicitly used and become part of the first dictum of the general provisions of the Fatwa of the Indonesian Ulema Council Number: 1 / MUNAS VII / MUI / 5/2005 concerning Protection of Intellectual Property Rights (IPR). In the first dictum several things are defined as follows ${ }^{21}$ :

1. Definition of Intellectual Property (IC), namely; "Wealth that arises from the results of brain thinking that produces a product or process that is useful to humans and is recognized by the State based on applicable laws and regulations".

2. Definition of Intellectual Property Rights (IPR), namely; "The right to enjoy economically the results of an intellectual creativity of the person concerned so as to provide private rights for him to register, and obtain protection for his intellectual work".

3. The state's obligation to the holder / owner of IPR, namely; "Granting exclusive rights to the registrant and / or the owner as a legal right holder where the right holder has the right to prohibit other people who, without their consent or rights, trade or use these rights in all forms and ways".

4. The purpose of IPR recognition by the state, namely; "So that everyone is motivated to produce their creativity in the interest of the wider community".

21 Indonesian Ulema Council Fatwa Number: 1/MUNAS VII/MUI/5/2005 Regarding the Protection of Intellectual Property Rights (IPR), the First Dictum General Provisions 
5. IPR consists of:

a. The right to protect plant varieties, the definition follows the provisions of Article 1 Number 2 of the Law of the Republic of Indonesia Number 29 of 2000 concerning Protection of Plant Varieties.

b. Trade Secret Rights, the definition follows the provisions of Article 1 Number 1, 2 and Article 4 of the Law of the Republic of Indonesia Number 30 of 2000 concerning Trade Secrets.

c. The Right to Industrial Design, the definition follows the provisions of Article 1 number 5 of the Law of the Republic of Indonesia Number 31 of 2000 concerning Industrial Design.

d. The Right to Integrated Layout Design, the definition follows the provisions of Article 1 Number 6 of the Law of the Republic of Indonesia Number 32 of 2000 concerning Integrated Layout Design. In this case there was a writing error in the Fatwa of the Indonesian Ulema Council Number: 1 / MUNAS VII / MUI / 5/2005 concerning Protection of Intellectual Property Rights (IPR), which should have written "Integrated Circuit Layout Design", but in fact it was written "Design Integrated Layout ".

e. Patents, the definition follows the provisions of Article 1 Number 1 of the Law of the Republic of Indonesia Number 14 of 2001 concerning Patents.

f. The right to a mark, the definition follows the provisions of Article 3 of the Law of the Republic of Indonesia Number 15 of 2001 concerning Marks.

g. Copyright, the definition follows the provisions of Law of the Republic of Indonesia Number 19 of 2002 concerning Copyright.

Some things that can be observed related to the first dictum of the Indonesian Ulema Council Fatwa Number: 1 / MUNAS VII / MUI / 5/2005 concerning Protection of Intellectual Property Rights (HKI) are as follows:

1. Contains definitions that are generally contained in Article 1 of the law in Indonesia.

2. IPR consists of seven types of protection. Thus the Geographical Indications and the Indications of Origin whose arrangements are contained in Chapter VII of the Law of the Republic of Indonesia Number 15 of 2001 concerning Trademarks do not obtain the intended fatwa protection.

3. The definition of Copyright refers to the provisions of Article 1 Number 1 of the Law of the Republic of Indonesia Number 19 of 2002 concerning Copyright, meanwhile the provisions of the said fatwa do not mention the provisions of the article. This is different from other definitions which clearly state the provisions of the article.

The definitions contained in the Indonesian Ulema Council Fatwa Number: 1 / MUNAS VII / MUI / 5/2005 concerning Protection of Intellectual Property Rights (IPR), which explicitly refer to certain statutory provisions 
have advantages in terms of integration between fatwa which is meant by positive law in Indonesia. Such thinking is unique in a law state that adheres to the European legal tradition of continental (civil law), where one of its characteristics is the codification of the law ${ }^{22}$, namely the codification of the law for the protection of Intellectual Property Rights. However, this also has shortcomings in the event that the laws and regulations referred to for one reason or another are no longer available, so that definition becomes debatable, whether the definition becomes invalid or continues to apply.

Of the seven laws related to IPR protection in Indonesia which are an inherent part of the fatwa, three of them have been declared null and void and replaced with new laws. The three laws are as follows:

1. Law of the Republic of Indonesia Number 19 of 2002 concerning Copyright is declared null and void and replaced by Law of the Republic of Indonesia Number 28 of 2014 concerning Copyright.

2. Law of the Republic of Indonesia Number 14 of 2001 concerning Patents shall be declared no longer valid and replaced by Law of the Republic of Indonesia Number 13 of 2016 concerning Patents.

3. Law of the Republic of Indonesia Number 15 of 2001 concerning Trademarks is declared no longer valid and is replaced by Law of the Republic of Indonesia Number 20 of 2016 concerning Trademarks and Geographical Indications.

Because the definitions of Copyright, Patents and Trademarks contained in the intended fatwa refer to the definitions contained in the law (positive law), it is interesting to note whether the replacement of the intended law changes the definition of Copyright, Patents and Trademarks. or not. This is described below.

Table 1. Comparison of Definitions

\begin{tabular}{|c|c|c|c|}
\hline No & Definition & Old Act & New Act \\
\hline 1 & Copyright & $\begin{array}{l}\text { "Copyright is the exclusive } \\
\text { right for an Author or } \\
\text { recipient of the right to } \\
\text { announce or reproduce his } \\
\text { Work or give permission for } \\
\text { it by not reducing } \\
\text { restrictions } \\
\text { according to the legislation } \\
\text { in force ", Article } 1 \text { Number } \\
1 \text { of the Law of the Republic } \\
\text { of Indonesia Number } 19 \text { of } \\
2002 \text { concerning Copyright }\end{array}$ & $\begin{array}{l}\text { "Copyright is the exclusive } \\
\text { right of the creator that arises } \\
\text { automatically based on the } \\
\text { declarative principle after a } \\
\text { work is realized in tangible } \\
\text { form without reducing } \\
\text { restrictions in accordance with } \\
\text { statutory provisions", Article } 1 \\
\text { Number } 1 \text { of the Republic of } \\
\text { Indonesia Law No. } 28 \text { of } 2014 \\
\text { concerning Copyright }\end{array}$ \\
\hline
\end{tabular}

22 Nurul Qamar. Comparison of Civil Law System and Judicial System and Common Law System. Pustaka Refleksi, Makassar, 2010, Page. 41 


\begin{tabular}{|c|c|c|c|}
\hline 2 & Patent & $\begin{array}{l}\text { "Patent is an exclusive right } \\
\text { granted by the State to an } \\
\text { Inventor for the results of } \\
\text { his invention in the field of } \\
\text { technology, which for a } \\
\text { certain period of time carries } \\
\text { out his own invasion or } \\
\text { gives his approval to } \\
\text { another party to implement } \\
\text { it", Article } 1 \text { Number } 1 \text { of the } \\
\text { Law of the Republic of } \\
\text { Indonesia Number } 14 \text { of } \\
2001 \text { About Patents }\end{array}$ & $\begin{array}{l}\text { "A patent is an exclusive right } \\
\text { granted by the state to an } \\
\text { inventor for his invention in } \\
\text { the field of technology for a } \\
\text { certain period of time carrying } \\
\text { out the invention himself or } \\
\text { giving approval to other } \\
\text { parties to implement it". } \\
\text { Article } 1 \text { Number } 1 \text { of the Law } \\
\text { of the Republic of Indonesia } \\
\text { Number } 13 \text { Year } 2016 \\
\text { Regarding Patents }\end{array}$ \\
\hline 3 & Brand & $\begin{array}{l}\text { "Right to Mark is an } \\
\text { exclusive right granted by } \\
\text { the State to the owner of a } \\
\text { Mark that is registered in the } \\
\text { General Register of Marks } \\
\text { for a certain period of time } \\
\text { by using the Mark himself or } \\
\text { giving permission to other } \\
\text { parties to use it", Article } 3 \text { of } \\
\text { the Republic of Indonesia } \\
\text { Law Number } 15 \text { Year } 2001 \\
\text { About Brands }\end{array}$ & $\begin{array}{l}\text { "The right to a mark is an } \\
\text { exclusive right granted by the } \\
\text { state to the owner of a } \\
\text { registered mark for a certain } \\
\text { period of time by using the } \\
\text { mark himself or giving } \\
\text { permission to other parties to } \\
\text { use it", Article } 1 \text { Number } 5 \text { of } \\
\text { the Republic of Indonesia Law } \\
\text { Number } 20 \text { Year } 2016 \\
\text { concerning Trademarks And } \\
\text { Geographical Indications }\end{array}$ \\
\hline
\end{tabular}

Based on the description in the table above it can be seen that the substance of the definitions can be said to be the same, although specifically related to the brand definition the position of the article in the new law is different from the position of the article in the old law. The problem now is the provision as below:

1. Provisions of Article 124 of the Law of the Republic of Indonesia Number 28 Year 2014 Regarding Copyright; "When this Law comes into force, Law Number 19 of 2002 concerning Copyright (Statute Book of the Republic of Indonesia Number 85 of 2002, Supplement to Statute Book of the Republic of Indonesia Number 4220) is revoked and declared invalid."

2. Provisions of Article 171 of the Republic of Indonesia Law Number 13 Year 2016 Regarding Patents; "When this Law comes into force, Law Number 14 of 2001 (Statute Book of the Republic of Indonesia Number 109 of 2001, Supplement to Statute Book of the Republic of Indonesia Number 4130), is revoked and declared invalid."

3. Provisions of Article 107 of the Law of the Republic of Indonesia Number 20 Year 2016 Regarding Geographical Marks and Indications; "When this Law comes into force, Law Number 15 of 2001 concerning Marks (State 
Gazette of the Republic of Indonesia Number 110 of 2001, Supplement to the State Gazette of the Republic of Indonesia Number 4131) is revoked and declared invalid".

Based on the description above it can be seen that currently the Indonesian Ulema Council Fatwa Number: 1 / MUNAS VII / MUI / 5/2005 concerning Protection of Intellectual Property Rights (IPR) refers to three laws that have been revoked and declared invalid. Thus it is fitting and proper that a portion of the first dictum of the fatwa, which obviously refers to laws that have obviously been revoked and declared no longer valid, for law is considered as no longer valid.

The above paragraph gives us an understanding that currently the Indonesian Ulema Council Fatwa Number: 1 / MUNAS VII / MUI / 5/2005 concerning Protection of Intellectual Property Rights (IPR) does not provide protection against; (1) Copyright, (2) Patents, (3) Trademarks, (4) Geographical Indications, and (5) Indications of Origin. Thus the next discussion will only be related to; (1) Plant Variety Protection Rights, (2) Trade Secret Rights, (3) Industrial Design Rights, and (4) Integrated Circuit Layout Design Rights.

The second dictum on the general provisions of the Indonesian Ulema Council Fatwa Number: 1 / MUNAS VII / MUI / 5/2005 concerning Protection of Intellectual Property Rights (IPR) includes four things, namely:

1. IPR is equal to wealth.

2. Protected IPRs must not conflict with Islamic law.

3. IPR can be the object of a contract, be forgiven, and bequeathed.

4. Violation of IPR protection is wrong and the punishment is haram.

Placement of IPR as wealth by MUI fatwa is in line with the purpose of IPR protection provided by law, namely; in essence, it provides protection to the IPR owner who is intended to utilize the economic value of his IPR, which in this context IPR can also be interpreted as a wealth for the owner.

The IPR protected by the MUI fatwa must not conflict with Islamic law, in various forms and manifestations. Thus only a portion of IPR that is protected by national law can also be protected by the intended MUI fatwa. As an example; IPRs related to food / drinks, including drugs, which contain alcohol certainly cannot be protected by the MUI fatwa because the use of alcohol for food / drinks, including drugs, is basically unlawful according to Islamic law ${ }^{23}$.

Intellectual Property Rights can be used as an object of agreement, forgiveness, and inheritance. In other words, IPRs can be transferred. This is in accordance with the provisions of the legislation related to IPR protection which allows IPR to be transferred. What is meant by a contract here must refer to the contract as contained in Article 20 of the Compilation of Sharia Economic Laws. The transfer of other rights permitted by the MUI

23 Indonesian Ulema Council Fatwa Number: 11 Tahun 2009 Regarding Alcohol Law, Second Dictum on Legal Provisions 
fatwa is through means of being represented and bequeathed, while in Islamic law it is also known as the transfer of rights by means of grants and wills. The transfer of rights by means of grants and wills is also known in legislation relating to IPR protection, for example:

1. Article 40 paragraph (1) of the Law of the Republic of Indonesia Number 29 Year 2000 concerning Protection of Plant Varieties; "(1) PVP rights can be transferred or transferred because: a. inheritance; b. grant; $c$. will; d. agreement in the form of a notarial deed; or e. other reasons justified by law".

2. Article 5 paragraph (1) of the Law of the Republic of Indonesia Number 30 of 2000 concerning Trade Secrets; "Trade Secret Rights can be transferred or transferred by: a. inheritance; b. grant; c. will; $d$. written agreement; or e. other reasons justified by statutory regulations ".

3. Article 31 paragraph (1) of the Law of the Republic of Indonesia Number 31 Year 2000 Concerning Industrial Design; "Industrial Design Rights can be transferred or transferred by: a. inheritance; b. grant; c. will; d. written agreement; or e. other reasons justified by statutory regulations ".

4. Article 23 paragraph (1) of the Law of the Republic of Indonesia Number 32 Year 2000 Concerning Layout Design of Integrated Circuits; "The Right to Layout Design of Integrated Circuits can be switched or transferred by: a. inheritance; b. grant; c. will; d. written agreement; or e. other reasons justified by statutory regulations ".

Based on the description above it can be seen that in the law related to IPR protection there is no known transfer of rights by way of waqaf. Nevertheless the transfer of rights by way of waqf can be done by using the provisions of the transfer of rights by means of a written agreement (written waqf agreement). Or you can also use a clause on the transfer of rights by other reasons justified by statutory regulations. The issue of waqf is regulated in the Law of the Republic of Indonesia Number 41 of 2004 concerning Waqf. In this case, the transfer of rights to IPRs that have provisions in the legislation related to IPR protection is broader than the transfer of rights as stipulated in the Indonesian Ulema Council Fatwa Number: 1 / MUNAS VII / MUI / 5/2005 Concerning Rights Protection Intellectual Property (IPR).

Violation of IPR is a crime and the law is haram. In everyday life the threat of "haram" punishment certainly does not have any impact. Thus the threat of punishment is more social in nature with the stigma of ${ }^{24}$ "having committed an illicit act" is expected that people do not violate IPR. In fact it is very possible that the stigma does not have a beneficial impact on IPR protection because the level of public awareness about the importance of respect for IPR still needs to be increased again.

24 "Negative traits attached to a person because of the influence of the environmen". KBBI Daring, Stigma, https://kbbi.kemdikbud.go.id/entri/stigma, downloaded Sunday, May 17, 2020 
The second dictum of the Indonesian Ulema Council Fatwa Number: 1 / MUNAS VII / MUI / 5/2005 concerning Protection of Intellectual Property Rights (IPR) which basically states that violations of IPRs are acts of tyranny and the law is haram can actually be more "fearful" by appealing " illicit acts "(violation of IPR) into the realm of Islamic criminal law (jurisprudent jinayah). "Jinayah is a term for actions which are prohibited by the Shara, whether those actions pertain to the soul, property, or others" 25 . While Imam Mawardi with the same intention does not use the term jinayah, but uses the term jarimah which is defined as; "Any prohibition on syara (doing things that are forbidden and or leaving things that are required that are threatened with punishment of had or ta'zir)"126. With more or less the same intention, Hanafi argues that the rahmah is the prohibitions of Allah which are threatened with the punishment of had or $\operatorname{ta}^{\prime} \mathrm{Zir}^{27}$. Criminal liability in the Islamic criminal law system is called al-mas'uliyah al-jinaiyyah, namely; the imposition of a person who does an act, or does not do an act, which is done of his own volition, while the person concerned knows the purpose and consequences of his actions ${ }^{28}$.

Violations of IPR may not be known in Islamic criminal law, but haram (prohibited acts) certainly gets punished in the Islamic criminal system. In this case Islamic criminal law is the law of God which contains benefits for humans ${ }^{29}$. Nash (Al-Qur'an and Hadith) that forbid (prohibit) or require an act determined by Allah SWT which is then conveyed to humans through His Messenger. There are Nash which are explicit, but there are also those that are implicit in the form of general legal principles. There may be no texts related to IPR violations, but there are texts related to theft. If within certain limits an IPR violation can be analogous to theft, then the IPR violation may be subject to punishment as a penalty against the perpetrator of the theft.

Nash related to criminal acts of theft include:

1. "Men who steal and women who steal cut off both of their hands (as) vengeance for what they do and as torture from Allah. And Allah is Mighty, Most Wise "(Surat al-Maidah: 38).

2. "It is reported from Abi Hurairah that the Prophet Muhammad, said: Allah curse the thief who stole an egg, then (his punishment) cut off his hand; and who stole the rope then (his sentence) his hand was cut off "(HR. Bukhari) ${ }^{30}$.

25 Rahmad \& Hakim, Islamic Criminal Law (Jinayah Jurisprudence), Pustaka Setia, Bandung, 2000, Page. 12

26 Mawardi, Al-Ahkam al-sulthoniyah wa al-wilayah al-Diniyah, Mustafa Halabi, Mesir, 1773, Page. 219

27 A. Hanafi, Principles of Islamic Criminal Law, Bulan Bintan, Jakarta, 1986, Page. 1

28 Ahmad Hanafi, Principles of Islamic Criminal Law, Bulan Bintang, Jakarta, 1993, Page. 154

29 Zainuddin Ali, Islamic Islamic Law, Sinar Grafika, Jakarta, 2007, Page. 1

30 Bukhari, Sahih Abi Abdillah Al-Bukhari bin Sarhi Karomani, juz 22, Dar Al-Fikr, Bairut, PAGE. 192 
According to the meaning of the word theft is "process, method, act of stealing" 31 , while stealing according to the meaning of the word is "taking someone else's property without permission or illegally, usually by stealth" ${ }^{\text {"32 }}$. Meanwhile, according to the term syara, theft is when someone in a conscious condition and has grown up to take the property of another person in a certain amount secretly from their usual storage in ways that cannot be justified by law, and also not because of doubt ${ }^{33}$. What is meant by "a certain amount" here according to Syarbin Khotib is a quarter of a dinar $^{34}$. Thus the elements of a criminal act of theft are as follows ${ }^{35}$ :

1. Taking other people's belongings.

2. The item was taken surreptitiously.

3. The goods are in the storage area.

If the "IPR violation" will be analogous to theft, then the IPR violation action must be able to fulfill the elements of the theft. First, taking other people's belongings; if the rights (Intellectual Property Rights) are analogous to the same as goods, then the element of "taking other people's belongings" can be fulfilled by violations of IPR, because actually the infringement of IPR is done by taking without rights, Intellectual Property Rights belonging to another person. In this case the conversion process occurs from something that is intangible (rights) to something that is tangible (goods).

Rights are something that is intangible (not material, not physical), but goods are something tangible (material, physical). Conversion from rights to goods, or from intangible to tangible, and vice versa, is something that is very likely to occur because intangible and tangible are "two sides of the same coin". As an example; Apple brand mobile phone (iphone); the price is expensive because it has various advantages, one of which is because it is made using high technology. In this case the iphone is expensive because the "goods" are indeed of high quality. Thus Apple is tangible. Then the Apple brand is also used unlawfully by other mobile phones, and it turns out that the cellphone's price is "expensive". In this case Apple which is intangible (brand) is worth "expensive", not the goods (mobile). Based on these illustrations it can be understood that the iphone is worth "expensive" because the goods are of high quality (tangible) and or because the brand is Apple (intangible).

Violations of IPR protection can certainly be done clandestinely, namely; done without the knowledge of, or without the permission of, the IPR holder. The word "secretly" here cannot be interpreted as "(quietly); not

31 KBBI Daring, Theft, https://kbbi.kemdikbud.go.id/entri/pencurian, downloaded Sunday, May 17,2020

32 KBBI Daring, Steal, https://kbbi.kemdikbud.go.id/entri/mencuri, downloaded Sunday, May 17,2020

33 Ali as-Shabuni. Tafsir Ayat Ahkam as-Shabuni Volume I, Translate Muammal Hamidi dan Imran A. Manan, Dar al-Ilmiyah, 1995, Page. 499

34 Marsum, Jinayat (Islamic Criminal Law), UII Press Yogyakarta, Yogyakarta, 1991, Page. 94

35 Sayyid Sabiq, Sunnah Fiqh, Volume 9, Translate Mohamad Nabhan Husein, Maarif, Bandung, 1984, Page. 216 
overtly ${ }^{136}$, because in reality many IPR violations were carried out openly, for example; pirated VCD sales by roadside traders or in shops in shopping centers. In some markets where clothing sales in the city of Bandung, can be found pants with famous brands that are sold at low prices. It's hard to believe that pants with these famous brands are "authentic". Based on the description, the element "goods (rights) are taken (used) clandestinely" can be fulfilled

The element "the goods are in the place of storage" must be interpreted as "rights (the analogy of the goods) are controlled by the owner (analogy of" storage"). Violation of IPR protection is done by taking or controlling or using in violation of the law of rights (Intellectual Property Rights) which are controlled by the owner of said rights. That is because the holder (owner) of the rights (Intellectual Property Rights) in fact never gave permission to the perpetrators of IPR violations to use the rights of the holder (owner) of that right. Based on the description, the elements in question can be fulfilled.

In the Criminal Code (KUHP), the crime of theft is contained in Chapter XXII Article 362 - Article 367. "Anyone who takes things, wholly or partly owned by another person, with the intention to be owned illegally, threatened with theft, with a maximum imprisonment of five years or a maximum fine of nine hundred rupiah" ${ }^{17}$. The elements of this article are as follows:

1. Whoever.

2. Take something.

3. This item belongs in whole or in part to another person.

4. With the intention to be owned illegally.

Although according to Sayyid Sabiq the element of people (legal subjects) who commit theft is not an element of theft, but if you look at the definition of theft according to syara, "someone in a state of conscious and mature" becomes part of the element of criminal acts of theft. This is consistent with the elements of article theft according to Article 362 of the Criminal Code. The element of "taking something's goods" and the element of "such goods in whole or in part belonging to someone else" in Article 362 of the Criminal Code corresponds to the element of "taking goods belonging to someone else". While the element "with the intention to be owned illegally is incompatible with the element of theft according to Sayyid Sabiq, but in accordance with the definition of theft according to sharia, namely; "In ways that cannot be justified by law". Based on this description it can be understood that the elements of article 362 of the Criminal Code (theft) are in conformity with the element of criminal acts of theft according to syara (Islamic law).

Legislation that serves to provide protection, in this case IPR protection, is of course complemented by articles that provide sanctions

36 KBBI Daring, Secret/y, https://kbbi.kemdikbud.go.id/entri/sembunyi-sembunyi, downloaded Sunday, May 17, 2020

37 Criminal Code (KUHP), Article 362. 
against those who violate these protections. This can be described as the table below.

Table 2. Criminal Provisions

\begin{tabular}{|c|l|l|}
\hline No & \multicolumn{1}{|c|}{ Constitution } & \multicolumn{1}{|c|}{ Criminal Provisions } \\
\hline 1 & $\begin{array}{l}\text { Law of the Republic of Indonesia } \\
\text { Number 29 Year 2000 Regarding } \\
\text { Protection of Plant Varieties }\end{array}$ & $\begin{array}{l}\text { Article 71 - Article 75. Criminal } \\
\text { offenses. Imprisonment sanctions } \\
\text { and fines }\end{array}$ \\
\hline 2 & $\begin{array}{l}\text { Law of the Republic of Indonesia } \\
\text { Number 30 of 2000 concerning Trade } \\
\text { Secrets }\end{array}$ & $\begin{array}{l}\text { Article 17. Delict of complaint. } \\
\text { Imprisonment sanctions and / or } \\
\text { fines }\end{array}$ \\
\hline 3 & $\begin{array}{l}\text { Law of the Republic of Indonesia } \\
\text { Number 31 of 2000 concerning } \\
\text { Industrial Design }\end{array}$ & $\begin{array}{l}\text { Article 54. Decision on complaint. } \\
\text { Imprisonment sanctions and / or } \\
\text { fines }\end{array}$ \\
\hline 4 & $\begin{array}{l}\text { Law of the Republic of Indonesia } \\
\text { Number 32 of 2000 concerning } \\
\text { Layout Design of Integrated Circuits }\end{array}$ & $\begin{array}{l}\text { Article 42. Decision on complaint. } \\
\text { Imprisonment sanctions and / or } \\
\text { fines }\end{array}$ \\
\hline
\end{tabular}

Based on the data in table 2 above it can be seen that only violations of the protection of plant varieties are categorized as crimes so that the criminal process uses ordinary offense, which can be processed by the police without first waiting for complaints from those who feel disadvantaged. Whereas violations of trade secret protection, industrial design, and layout design of integrated circuits are categorized into complaint offenses where the police can only carry out law enforcement processes after complaints from parties who feel disadvantaged.

Based on the overall discussion, it can be seen that the potential for IPR protection provided by the MUI fatwa could actually be more "frightening" for the perpetrators of IPR violations in Indonesia, because the IPR violations can be categorized as illicit acts, namely theft where the punishment is "cutting off hands". That it is true that Islamic criminal law nationally is not applied in Indonesia. Even so, psychologically the threat of "cutting off hands" for perpetrators of criminal acts of IPR violations in Indonesia is expected to a certain degree can provide a deterrent effect for perpetrators of criminal acts of IPR violations.

\section{CONCLUSION}

Based on the discussion above, it can be concluded as follows: First, Fatwa of the Indonesian Ulema Council Number: 1 / MUNAS VII / MUI / 5/2005 concerning Protection of Intellectual Property Rights (IPR) is no longer relevant at this time because there are several laws and regulations 
being an inherent part of the fatwa has been revoked and declared no longer valid. Thus, some of the MUI fatwas immediately became out of legal force. Second, in order to be implemented effectively, the Fatwa of the Indonesian Ulema Council Number: 1 / MUNAS VII / MUI / 5/2005 concerning Protection of Intellectual Property Rights (HKI) must be replaced with a similar fatwa with several improvements.

Researchers suggest: First. Efforts to make efforts to formulate fatwas related to IPR protection can be integrated with the laws and regulations related to the protection of KHI so that the two can complement and strengthen each other. Second, a new MUI fatwa related to IPR protection will be formulated because the Fatwa of the Indonesian Ulema Council Number: 1 / MUNAS VII / MUI / 5/2005 concerning Protection of Intellectual Property Rights (IPR) is not in accordance with the development of legislation.

\section{BIBLIOGRAPHY}

\section{Book:}

A. Hanafi, 1986, Principles of Islamic Criminal Law, Bulan Bintan, Jakarta;

Ahmad Hanafi, 1993, Principles of Islamic Criminal Law, Bulan Bintang, Jakarta;

Bambang Sunggono, 2013, Legal Research Methodology, Raja Grafindo Persada, Jakarta;

Bukhari, Sahih Abi Abdillah Al-Bukhari bin Sarhi Karomani, juz 22, Dar Al-Fikr, Bairut;

Darmansyah, 1986, Basic Social Sciences, Usaha Nasional, Surabaya;

Herimanto \& Winarno, 2008, Basic Social and Cultural Sciences, Bumi Aksara, Jakarta;

H.M. Arifin Noor, 1999, Basic Social Knowledge, Pustaka Setia, Bandung;

Johnny Ibrahim, 2012, Normative Law Theory \& Research Methodology, Bayumedia Publishing, Malang;

Marsum, 1991, Jinayat (Islamic Criminal Law), UII Press Yogyakarta, Yogyakarta;

Mawardi, 1773, Al-Ahkam al-sulthoniyah wa al-wilayah al-Diniyah, Mustafa Halabi, Mesir;

Nurul Qamar. 2010. Comparison of Civil Law System and Judicial System and Common Law System. Pustaka Refleksi, Makassar;

Peter Mahmud Marzuki, 2013, Revised Edition of Legal Research, Kencana, Jakarta;

Rahmad \& Hakim, 2000, Islamic Criminal Law (Jinayah Jurisprudence), Pustaka Setia, Bandung; 
Salim HS. Dan Erlies Septiana Nurbani, 2013, Application of Legal Theory in Thesis and Dissertation Research, RajaGrafindo Persada, Jakarta;

Syamsu Yusuf \& Juntika Nur Ihsan, 2008, Personality Theory, Rosda Karya, Bandung;

Sayyid Sabiq, 1984, Sunnah Fiqh, Volume 9, Translate Mohamad Nabhan Husein, Maarif, Bandung;

W.A. Gerungan, 1996, Social Psychology, Eresco, Bandung;

William J. Goode, 2007, Family Sociology, Bumi Aksara, Jakarta;

Zainuddin Ali, 2007, Islamic Islamic Law, Sinar Grafika, Jakarta;

\section{Journal:}

Ali as-Shabuni. 1995, Tafsir Ayat Ahkam as-Shabuni Volume I, Translate Muammal Hamidi dan Imran A. Manan, Dar al-IImiyah;

Cindi Muhrani Dewi, 2017, Analysis of the MUI fatwa No. 1 / MUNAS VII / MUI / 15/2005 Concerning Protection of Intellectual Property Rights Against Illegal Downloading Songs (Case Study of Muamalah Department Students, Faculty of Sharia and Law UINSU), Fakultas Syariah Dan Hukum Universitas Islam Negeri Sumatera Utara;

Edy Santoso, 2014, Islamic Law Concept On International Trade Law Related To Copyright Issues In Indonesia And Turkey, Research Report, Turkish Religious Foundation, Centre for Islamic Studies, Istanbul;

Meilanny Budiarti S., Unravel the Basic Concepts of Humans as Individuals Through Social Relations They Build, Prosiding KS: Riset \& PKM, Vol.: 4, No.: 1, ISSN: 2442-4480;

Suri Maghfiraningsih, 2020, Legal Protection of Trademark Rights in the Perspective of Islamic Law, E-Journal of Legal Fatwa, Faculty of Law, Tanjungpura University, Vol 3, No 1 (2020).

\section{Regulations:}

Criminal Code (KUHP);

Indonesian Ulema Council Fatwa Number: 1/MUNAS VII/MUI/5/2005 Regarding the Protection of Intellectual Property Rights (IPR), the First Dictum General Provisions;

Indonesian Ulema Council Fatwa Number: 11 Tahun 2009 Regarding Alcohol Law, Second Dictum on Legal Provisions;

\section{Website:}

KBBI Daring, Common sense, https://kbbi.kemdikbud.go.id/entri/akal\%20budi, downloaded on Friday May 15, 2020;

KBBI Daring, Human, https://kbbi.kemdikbud.go.id/entri/manusia, downloaded on Friday May 15, 2020;

KBBI Daring, Individual, https://kbbi.kemdikbud.go.id/entri/individu, downloaded on Friday May 15, 2020; 
KBBI Daring, Secretly, https://kbbi.kemdikbud.go.id/entri/sembunyi-sembunyi, downloaded Sunday, May 17, 2020;

KBBI Daring, Steal, https://kbbi.kemdikbud.go.id/entri/mencuri, downloaded Sunday, May 17, 2020;

KBBI Daring, Stigma, https://kbbi.kemdikbud.go.id/entri/stigma, downloaded Sunday, May 17, 2020;

KBBI Daring, Theft, https://kbbi.kemdikbud.go.id/entri/pencurian, downloaded Sunday, May 17, 2020;

M. Sholeh Kurniawan \& Abdullah Alawi, Four Humans That Live Will Not Be Losses, https://www.nu.or.id/post/read/73580/empat-manusiayang-hidup-tak-akan-rugi-, downloaded Saturday, May 16, 2020; 